\title{
Using Real Options to Help Build the Business Case for CRM Investment
}

\author{
by \\ Stan Maklan, BSc, MBA \\ Professor Simon Knox, \\ Dr Lynette Ryals, MA \\ $\mathrm{PhD}$ \\ BSc, $\mathrm{PhD}^{*}$ \\ Professor of Brand \\ Marketing \\ Centre for Advanced \\ Centre for Advanced \\ Research in Marketing \\ Research in Marketing \\ Cranfield School of \\ Management \\ Cranfield University \\ Management \\ (Oxon), MBA, PhD, FSIP \\ Senior Lecturer in \\ Marketing \\ Centre for Advanced \\ Research in Marketing \\ Cranfield School of \\ Cranfield \\ Bedford MK43 0AL \\ Tel: 01234751122 \\ Tel: 01234751122 \\ Management \\ Fax: 01234751806 \\ email: \\ Fax: 01234752691 \\ email: \\ stanmaklan@hotmail.com \\ s.knox@cranfield.ac.uk \\ Tel: 01234751122 \\ Fax: 01234752691 \\ email: \\ lynette.ryals@cranfield.ac. \\ uk \\ * Address for correspondence \\ (C) 2004/05, Cranfield School of Management
}




\title{
Using Real Options to Help Build the Business Case for CRM Investment
}

\author{
Abstract \\ While CRM (Customer Relationship Management) practices are being adopted widely, \\ research suggests that most CRM programmes fail in their dual objective of creating \\ superior customer value and increasing profits for the firm.
}

This article questions the basis on which the business case for CRM investments is made. It highlights shortcomings with traditional cash-flow analysis (DCF and NPV), how these shortcomings inhibit successful CRM implementation and why senior managers may consider using Real Options thinking to address the limitations of DCF and NPV. A simulated case study illustrates how the use of Real Options in addition to NPV/DCF can impact decision making when preparing the business case for CRM investments. Such complimentary analyses help ensure that senior managers focus on both the activities that generate immediately-identifiable cash as well as the harder-to-quantify strategic aspects of customer relationships that generate longer-term customer value and profits. 


\section{Keywords}

CRM Investments; Real Options; Simulated Business Case

\section{Biographies}

\section{STAN MAKLAN BA MBA PhD Visiting Fellow}

Currently, Stan is a Visiting Fellow at the Cranfield School of Management and a Founding Partner of the Forge, a marketing consultancy. He spent the first 10 years of his career in marketing with Unilever Canada, UK and Sweden, where he was Marketing Director of its Toiletries business. He spent the following 10 years largely in consulting, most recently with Sapient, a leading builder of new economy businesses as a senior manager specialising in CRM and marketing strategy. Previously, Stan was a managing consultant with one of the world's largest IT-management consulting firms, CSC Computer Sciences. Stan established CSC UK's Customer Relationship Management practice and then moved to a role within its European Consulting and global management research unit (Research Services).

\section{SIMON KNOX BSc PhD Professor of Brand Marketing}

Simon Knox is Professor of Brand Marketing at the Cranfield School of Management in the UK and is a consultant to a number of multinational companies including McDonald's, Levi Strauss, DiverseyLever, BT and Exel. Upon graduating, he followed a career in the marketing of international brands with Unilever plc in a number of senior marketing roles in both detergents and foods. Since joining Cranfield, Simon has published over 100 papers and books on strategic marketing and branding and is a regular speaker at international conferences. He is a Director of the Cranfield Centre for Advanced Research in Marketing in the School and is currently leading a research team looking at the impact of Corporate Social Responsibility on Brand Management. His recent books include: "Competing on Value", FT Pitman (UK, Germany, the USA and China), "Creating a Company for Customers", FT Prentice-Hall (UK, Brazil and India) and "Customer Relationship Management", Butterworth-Heinemann.

\section{LYNETTE RYALS MA (Oxon) MBA PhD FSIP Senior Lecturer in Marketing}

Lynette began her career in the City as a fund manager and stockbroker trading UK equities, options and futures, and still lectures occasionally on finance issues. She then 
moved to a marketing company to work on corporate development and acquisitions, subsequently transferring into the consultancy arm of the same business group. Lynette is a Registered Representative of the London Stock Exchange and is the only woman in the UK to have passed the Fellowship examinations of the Society of Investment Professionals. She is co-author of "Customer Relationship Management: The Business Case", Butterworth-Heinemann. 


\section{Using Real Options to Help Build the Business Case for CRM Investment}

\section{Synopsis}

High rates of CRM failure can originate right at the business case stage where the investment decisions are made. Traditional discounted cash-flow analysis alone does not value or focus managerial attention upon the strategic long-term benefits of CRM: learning from customers, building customer advocacy and retention, and reduced market uncertainty. Through a simulated case study analysis, we illustrate how the addition of Real Options to discounted cash-flow can improve CRM investment decision making, encourage managers to verify critical assumptions and reduce both investment and business risk.

\section{Introduction}

The financial framework most often used in preparing business cases for Customer Relationship Management (CRM) may, perversely, inhibit such programmes from achieving their strategic and business objectives. Arguably, the traditional cash-flow analyses based upon Discounted Cash Flow (DCF) and Net Present Value (NPV) calculations are too limited a basis on which to make CRM investment decisions. This is because they undervalue returns and focus management attention on short-term cash-flow when, perhaps, the main benefits of customer relationship investments lie in building a strategic customer relationship asset. In other words, the long-term benefits of closer, deeper relationships with selected customers are difficult to quantify in cash terms since they can lead to reductions in the volatility of sales, market uncertainty and business risk. 
Given that CRM investments are usually strategically significant, with a value in the range of $\$ 60$ million to $\$ 200$ million for a highly complex installation which can take up to 3 years to install $\left(\right.$ Ebner et al, $2002^{1}$ ), the risk of business failure needs to be fully quantified. In the 1990s, the climate for CRM investment was more favourable and firms invested without fully considering these risks (Rigby et al, 2002 ${ }^{2}$ ). Their research suggests that $55 \%$ of all CRM projects haven't produced results, and some $20 \%$ of users report actual damage to long-standing customer relationships.

Today, business leaders are demanding a more rigorous approach to developing and presenting the business case for CRM investment. As a consequence, the senior managers involved in delivering the business case, usually a project team drawn from Marketing, Sales, IT and Customer Service, need to address fully the questions, "What steps can we take to reduce the uncertainty in the business case for CRM?" and "How do we reduce the risk of business failure if we adopt a more customer-centric approach through CRM?"

In this paper, we first identify the potential benefits of CRM investments to both customers and the firm. Then we explore the limitations of Discounted Cash Flow (DCF) and Net Present Value (NPV) in assessing how the CRM business case is presented. To counter the problems of risk and uncertainty left largely unanswered by a cash-flow analysis, we introduce the idea of Real Options as a risk-reduction step to help build the business case for CRM investment. This we do through a simulated case study of a telecom. equipment manufacturer actively considering a CRM investment. Initially, we 
develop a range of business case scenarios for the firm, together with a cash-flow calculation for each. These scenarios show wide variability, depending upon the business assumptions made, and we conclude that they significantly undervalue the likely effects of the firm's CRM investment and look very high risk indeed.

To help mitigate the uncertainty of such a large-scale investment, we introduce the idea of using Real Options in conjunction with traditional cash flow analysis to quantify the effects of trialling CRM before scale up as an alternative pathway for building the case for CRM investment. Although Real Options have been used to manage other IT investment risks $\left(\right.$ Benaroch, $2002^{3}$ ), as far as we are aware, this is the first time Real Options have been applied in the context of a CRM investment.

We close the paper by exploring the managerial implications of how this combination of cash-flow and Real Options helps reduce uncertainty in the CRM investment decision by introducing greater flexibility and a fact-based means of quantifying the business benefits.

\section{The Promise of CRM}

The promise of customer relationship management is captivating. For customers, CRM offers the potential for customised solutions, superior service and reduced costs over the lifetime of their relationship with the firm since shared knowledge of their business strategy, buying preferences and processes can be developed in a more systematic fashion. For the firm, the ability to gather customer data swiftly, identify the most valuable customers over time and increase customer retention through CRM is a highly desirable strategy since it positively impacts the firm's profitability (Reinartz et al, 
$2004^{4}$ ). Reinartz and co-researchers define CRM as "a systematic process to manage customer relationship initiation, maintenance and termination across all customer contact points to maximize the value of the relationship portfolio". Thus, CRM offers a potential win: win scenario for both the firm and its customers. However, the underlying reasons why both customers and firms choose to restrict the width of their business relationships require a fuller explanation of the mutual benefits of CRM from the perspective of the customer and of the business.

\section{The customer perspective}

Economic theory predicts that customers will buy from many suppliers to reduce costs and improve service (Palmer, $2000^{5}$ ). In reality, they willingly restrict their choice to a few preferred suppliers or brands (Gummesson, $1998^{6}$; Sheth, $1995^{7}$ ) with whom they either trust or collaborate closely (Christopher, $1998^{8}$, pp.190-191).

Whilst it seems that customers act contrary to their best economic interests, economists acknowledge that perhaps customers are acting rationally and avoiding transaction costs through relationships (Williamson, $1981^{9}$ ). Even where transaction costs are not a major consideration, customers may yet calculate that the total lifecycle costs of owning certain assets or procuring services are better managed through relationships (Degerature et al., $\left.1999^{10}\right)$.

In some markets, customer retention can be explained through the avoidance of switching costs; costs associated with switching from one product or service to a new one (Shapiro 
and Varian, $1998^{11}$ ). For example, companies may be reluctant to change software because of the attendant costs of retraining staff, repopulating databases and potential conflicts with other systems. Relationships with companies that listen, learn and respond through effective CRM practices can improve the customer's procurement experience. Where this happens, a virtuous cycle can develop: committed customers invest further in their focal suppliers by increasing their expenditure ( Verhoef, $2003^{12}$ ) and suppliers continually invest in process and quality improvements to support such strong and enduring customer relationships (Pine, Peppers and Rogers, $1995^{13}$ )

In summary, many customers prefer to deal with a small core of supplier-partners than to procure important supplies in the open market. Relationships are considered to add value and reduce costs, and buyers demonstrate a preference for building stable relationships over pure market transactions for all but straight commodities or low risk purchases.

\section{The business perspective}

In recent years, businesses have paid increasing attention to the profit impact of customer retention (Wyner, $1996^{14}$; Johnson, $\left.2002^{15}\right)$. Reichheld $\left(1996^{16}\right)$ makes a compelling argument that it is more profitable to focus on retaining customers rather than just maximising market share. Reichheld also maintains that these effects increase over time, so that the profitability of retained customers grows exponentially. Small changes in customer retention rates create a disproportionate increase in profitability.

It is the incentive of increasing customer retention and profitability through better CRM 
practices which often drives firms to develop a more customer-centric strategy. However, effective customer retention is contingent upon market segmentation as the starting point for the development of a firm's CRM strategy (Corner, 2002a ${ }^{17}$ ). Research suggests that most firms 'carry' many unprofitable customers who don't generate margins commensurate with the cost to serve them (Peppers and Rogers, $1997^{18}$ ). Peppers and Rogers argue that, through market segmentation and CRM, firms will be able to identify unprofitable customers and discontinue subsidising them so that resources can be redirected to retaining profitable customers, as well as attracting potentially profitable ones. For businesses supporting a large number of unprofitable customers, realigning the asset and cost base towards the segment of profitable customers can reduce the total asset base while increasing revenue. The impact upon shareholder value is obvious.

Recent research suggests that retained customers can also increase shareholder value by reducing the volatility of the firm's cash flow (Ryals, $2002^{19}$ ). Serving large numbers of transient customers makes cash flow volatile and creates fluctuations in short term assets, such as inventory and receivables. Investors demand greater return on investment to compensate for volatile cash flow. In addition, long-term customers may contribute valuable and unique learning to the firm (Wilson, $1996^{20}$ ). Knowledge gained by a firm from its customers through CRM over time can be translated into marketing action tailored to individual customers. Once a customer sees a supplier acting on information it has been given through CRM, there is a strong disincentive to start again with a competitive supplier. Learning from customers is particularly important in developing 
new products - there will be fewer expensive failures when customers can input early into the product development process (Thomke and von Hippel, 2002 ${ }^{21}$ ). This reduced development risk (or improved success of innovation) builds cash flow and reduces overall business risk. Indeed, many CRM advocates say that customers generate much more than cash flow; they 'teach' firms how to improve their business (Womack, Jones and Roos, $1990^{22}$ ).

While the promise of CRM is beguiling, the concomitant benefits of a more customercentric strategy can only be achieved through investing in technology, people and processes; both these CRM investment costs and the risk of business failure throughout the transition period can be very high.

Next, we explore what the main assumptions are in developing the business case for CRM and how the financial analysis is usually presented.

\section{Value Exchange and the CRM Business Case}

CRM creates symbiotic value for both customers and the business. The more customers 'teach' their suppliers, the more these businesses can support and respond to them. This value exchange process lies behind the most critical business assumptions about the CRM business case:

1 Trust is developed. Research suggests trust is developed through repeated experiences that meet or exceed customer expectations (Constable, 1998 ${ }^{23}$ ).

2 The CRM programme has integrity. Customers will continue 'teaching' firms about their needs and preferences for as long as they perceive benefit and therefore the CRM business plan must identify how the firm will learn and respond. 
3 There is mutual commitment. The business case must identify how and why customer commitment will increase over time, and how this increased commitment results in increased retention and reduced churn (Corner, 2002b $\left.{ }^{24}\right)$. Moreover, commitment can be leveraged commercially through increased sales, referrals and references. Research suggests that committed customers are likely to buy more from their preferred supplier through choice (Coyles and Gokey, 2002 25 ).

We argue that traditional financial analysis forces marketing and sales management to identify the outcome of the customer learning process at the outset of the CRM business case. So, senior managers write these assumptions into their sales targets, and design customer relationships around what the firm wanted to sell to them in the first place (Maklan, 2000 ${ }^{26}$ ). This compromises the win: win scenario that underpins any CRM strategy and, as we highlighted earlier, research suggests that most firms fail to achieve their targeted ROI from CRM investments (Fournier, Dobscha, and Mick, $1998^{27}$; Olazabal, 2002 $2^{28}$; PriceWaterhouseCoopers, $2004^{29}$ ).

\section{Traditional Financial Analysis of CRM}

Most CRM business cases are built upon traditional financial investment analysis tools; Discounted Cash Flow (DCF) and its associated calculation of Net Present Value (NPV) (Ryals, Knox and Maklan, 2000 ${ }^{30}$ ). Investment policy in most firms is to create shareholder value by determining whether expected returns on any investment exceed the risk-adjusted cost-of-capital for that type of investment.

In this financial model, CRM represents an investment in technology, people, new 
processes and marketing aimed at stimulating an increase in cash flow from customers in future years through higher revenues at lower sales and marketing costs (Knox et al, $\left.2003^{31}\right)$. This cash flow is discounted by an appropriate charge for capital to enable managers to compare investment and return on a like-for-like basis; that is, the present value of each. If Net Present Value (NPV) is positive when cash-flows are adjusted for the true cost of capital, then risk-adjusted return exceeds cost of investment. Sophisticated users of DCF estimate a residual value for the asset at the end of the planning period.

NPV is based upon estimated incremental cash-flows that are uncertain and there are no guarantees that the business case will be delivered once the programme(s) starts.

However, the forecasting process assumes that the business is a portfolio decision maker, making a series of investment decisions based on expected value. This is a risk reduction strategy; the business makes a large number of investments, none of which will expose it to unacceptable risk levels (Copeland, Koller and Murrin, $1995^{32}$ ). If each business case is honestly made, then investments that return less than forecast are balanced by those that exceed their estimates. Across a large number of investments, provided the charge for capital is appropriate, the use of DCF and NPV calculations should lead to decisions that increase shareholder value. 


\section{Limitations of Using DCF and NPV alone when estimating the benefits of CRM}

\section{Investment}

A number of critical assumptions made by these modelling techniques are not necessarily true for CRM investment. For instance:

1 DCF does not encourage measuring or fully valuing the non-cash value of customers which, consequently, may remain understated. Customers are worth more than cash; CRM should encourage customers to recruit new customers, to act as test markets for new ideas and to teach firms how to continually improve their operations. These customer relationship impacts can be substantial. For instance, the world's first telephone bank, first direct, claims $33 \%$ of new customers are generated from referral (Parmenter et al., $1997^{33}$ ). Software companies have long valued co-operative product development with leading customers and some firms may reduce prices to prestigious customers who are willing both to improve and endorse their offering.

2 The portfolio decision maker assumption may also be suspect. If an industry is in flux and there is a clear imperative to move to a more customer-centric business model, the firm may not have the luxury of repeated experimentation. When customer-centric change is a 'bet your business' initiative, DCF fails to value the consequence of getting it wrong; the greater the volatility (range of possible returns), the greater the option value of trialling, learning and postponing full commitment (Luehrman, $\left.1998^{34}\right)$.

3 Where there is great uncertainty around the outcome, a business case that looks at the 
NPV of a best estimate scenario is not always helpful (Copeland and Keenan, $\left.1998^{35}\right)$. When dealing with a very wide range of outcomes, discounting the cash flows of a mid-point estimate may fail to address adequately the variability and risk of the investment.

\section{Applying Real Options to Overcome These Limitations}

Real Options have recently been developed as a financial analysis tool to overcome the limitations of traditional financial analysis and the inability of DCF to reflect the value of learning and risk management. An option is the right (not the obligation) to buy or sell an underlying asset, traditionally a financial asset, at some future time. Real Options are so called because the underlying asset is real, not financial. They are useful for valuation in situations in which investment decisions can be deferred, piloted or scaled; this flexibility has value not just because an organisation can earn interest on the capital it retains but also because deferring a decision until the business situation clarifies reduces the uncertainty surrounding that decision (Buckley and Tse, $1996^{36}$ ).

The Real Options approach modifies DCF to capture the value of flexibility, learning and risk management in a project such as a major IT installation (McGrath and MacMillan, $2000^{37}$ ). The value of flexibility is the option to scale a project up (or down) as the opportunity and risks become clearer over time (McGrath, Ferrier and Mendelow, $2004^{38}$ ). In other words, the total value of the project is the NPV plus the value of the option to scale up, scale down, or to pull out (Exhibit A). 
Proponents of Real Options claim that they offer a superior pricing technique and decision support analysis to NPV alone; they are a particularly useful technique for evaluating major, future investments. Real Options have recently been demonstrated to have applications in marketing (Dias and Ryals, $2002^{40}$ ) and can offer significant benefits to marketers. For instance, by using Real Options, financial numbers can be put on difficult, hard-to-quantify issues, such as the value of learning from customers and risk reduction in business decisions. By adding back the value of learning and by reducing the risk of investment through exercising a Real Option, senior management is more able to demonstrate that apparently unattractive, or marginally attractive, CRM investments can sometimes have merit.

Like other researchers exploring the potential of Real Options in business investments generally (Boer, 2000 ${ }^{41}$, McGrath et al, 2004 ${ }^{42}$ ) and IT in particular ( Li and Johnson, $2002^{43}$, Kulatilaka et al, $\left.1999^{44}\right)$, the limitations of traditional financial analysis and the potential contribution of Real Options can be demonstrated through a simulated case study. For the purposes of this paper, our simulated case is $\mathrm{Westel}^{1}$, a telecoms hardware manufacturer struggling with a CRM business case.

\section{Developing the CRM Business Case at Westel}

Mary Green, Marketing Director of Westel, is leading a multi-disciplinary project team (the Team) tasked with preparing the CRM business case for a programme they believe

\footnotetext{
${ }^{1}$ Westel is a simulated case developed from actual incidents in our research and consultancy work in CRM. The issues discussed in the case are realistic in scope and scale.
} 
necessary for the firm's survival. Westel is a multinational company which provides telecoms. network hardware. It has an extensive product and service range, and an established reputation in solving complex, demanding problems. Its high-end products form the telecoms. backbone of many of its customers and command high margins. Once installed, Westel can confidently expect the lion's share of upgrades, extensions and ancillary services.

Currently, its annual turnover is $£ 500 \mathrm{M}$, it achieves a 40\% Gross Margin and a 5\% Net Contribution; SG\&A and R\&D represent 35\% of turnover. Westel is under attack from new competitors who combine solution design with hardware, installation, and network management. These firms are disintermediating Westel from its customers and the Board is worried that the firm will become a low-margin, hardware supplier to these upstarts. Mary is asked to put together a strategic response. How should Westel leverage its undoubted capabilities and extensive offerings to become a broad-based solution provider to its best customers?

The Team divides customers into three categories profitable; marginally profitable with substantial growth potential; and unprofitable with no prospect of becoming profitable (Peppers, Rogers and Dorf, $1999^{45}$ ). In the first two categories, Westel is only selling one-third of what it 'should' be achieving. Each business unit is focusing on its own offerings rather than total customer need. The firm is neither maximising opportunities across business units nor matching sales and marketing expenditure to the opportunity. Each business unit pursues its own targets. To address this, Westel needs to change from 
being product- to customer-centric. So, the Team recommends the creation of a key account management function to:

1 Integrate Westel offerings into bespoke, value-added customer solutions

2 Co-ordinate marketing, sales and service expenses, aligning them to priority customers and development programmes

3 Exploit the potential for referral. The Team knows that their customers network extensively and that Westel is not actively fostering customer referrals.

This programme requires substantial investment in sales and marketing, training, new technology and considerable reorganisation of the business.

\section{Estimating the CRM Business Case Using DCF}

The Finance Director had advised Mary to use 10-year cash flow forecast with a discount rate of $15 \%$. The costs of implementing a comprehensive CRM programme at Westel are easy to estimate; $£ 227 \mathrm{M}$ over ten years of which $£ 129 \mathrm{M}$ would be spent in the first three years alone (see notes to Appendix 1 for more details of these costs under "Successful CRM"). The Team is less confident about estimating incremental revenue. They estimate that turnover could increase dramatically through more effective cross-selling, customers acting as reference sites and customers directing Westel to develop as yet unforeseen new products and services. Mary is also convinced that Westel would reduce marketing and sales costs because she knows it is less expensive to serve retained customers than to continually recruit new ones. Although research costs would also rise, revenue would rise faster because customers would be helping to direct research thus making it more cost-effective. Finally, the Team believes that developing more comprehensive, long-term customer solutions as a result of a CRM programme would 
undoubtedly lead to an increase in gross margins.

In preparing the business case, the Team estimates the NPV of three scenarios:

1. "Successful CRM": The full CRM programme increases turnover and margin dramatically. Research, sales and marketing expenditures increase in absolute terms but fall as a percentage of turnover. The result of these effects is that in 10 years Westel almost doubles its turnover and increases its profit four-fold. Investment in R\&D increases by over forty percent in cash terms. (See Appendix 1 for a fuller explanation of Westel's projected income statements and NPVs of the three scenarios).

2. "No Change": There is no investment in CRM and consequently there is no change to the current business results with respect to revenue, cost or research investment.

3. "Gradual Decline": There is no investment in CRM but new competitors erode revenue and margin. In ten years, Westel's revenue is $25 \%$ lower and the firm is less than half as profitable. Marketing, Sales and R\&D spending are fixed as a percentage of turnover, but the $25 \%$ reduction in turnover leaves Westel less able to invest strategically and may compromise its future.

Despite the dramatic difference in the outcomes generated by the three scenarios, the NPV estimates demonstrate only a small difference between them in value (Figure 1). This is particularly true when comparing the "Successful CRM" and "No Change" scenarios, the comparison most salient to the Board. 


\section{Insert figure 1}

On an NPV basis alone, one cannot justify the huge investment in CRM that the Team believes is necessary for Westel's future prosperity. The problem is that nobody can prove with any credibility how well CRM will work or how much risk the business is at from competition. They have no basis in fact or experience for their estimates of CRM benefits. For example, the Team's belief that future product ideas would generate cost savings from better customer engagement is difficult to evaluate using DCF. To make the case for CRM using traditional financial analysis, Mary would have to increase her revenue forecasts well beyond levels that Westel's sales and marketing team could reasonably hope to achieve.

The Team is convinced that once a more customer-centric organisation was in place, Westel would find opportunities to reduce non-value-adding costs and identify winning new business ideas. Westel would be at the 'top-table' with its customers - gaining inside knowledge both of their evolving needs and by leading through innovative business practices. Without this access, Westel would lose its edge. Moreover, such a transformation takes time; if Westel does not begin implementing CRM soon, it may be too late by the time the business case becomes apparent.

The Team ponders what to do. Should they be even more ambitious about the revenue and margin upside even though they had no firm basis? Could they scale down CRM investment and still justify their growth assumptions? Should they try to convince the Board with 'soft', unquantifiable benefits? Should they try frightening the Board by 
painting a vision of doom if Westel allowed competitors to consolidate their hold on its best customers?

\section{Analysis of the Westel's CRM Business Case}

Westel needs to become customer-centric. But the only way to make a compelling business case based upon NPV is to make heroic assumptions about increased revenue, reduced cost and the risks of 'do nothing'. Forecasting large increases in revenue based on beliefs, experts' claims and hard-to-verify estimates of best practice is risky. Moreover, it assumes that you know the outcome of stronger customer relationships before entering into them. Locking Westel into pre-identified, cross-selling programmes and new product launches risks compromising the trust and learning which is at the heart of CRM. Investing more in the current business practices might generate more immediate return. Smaller initial investments giving short-term returns are favoured in NPV calculations because the discount rate - the time value of money - dramatically reduces benefits that are realised only in the long term.

But what will happen to Westel if Mary and Board are right about the increased competitive threat? How should senior managers assess the risk of being too cautious? If they fail to implement CRM now, can they come back later or will they have missed the chance forever?

DCF, not surprisingly, is best used when the situation can be described in cash flow terms. It fails to value what Westel will learn from its customers - a major CRM benefit. It also favours the short over the long term. DCF/NPV is not good at assessing the longer 
term, and potentially fatal risk facing Westel. If the competitive threat materialises, then DCF will lead Westel to seriously underestimate the benefits of the CRM investment case and by the time this is understood, it may be too late to implement the far-reaching changes needed to respond in a timely fashion.

\section{The Westel Solution: Applying Real Options}

The Team should avoid the use of heroic assumptions in the business. They are likely to be controversial when held up to scrutiny by experienced directors and the sales function. Moreover, if they are accepted, the pressure for immediate sales increases to customers will undermine any serious attempt at learning and responding to customers flexibly. The problem Mary faces is how to present financial data in a manner that promotes an intelligent discussion with the Board, identifies the key assumptions and risks of the investment and builds an informed consensus on the basis of valid information.

Reviewing the project, the Team generates a fourth scenario. Rather than an all-ornothing rollout of CRM, they identify a limited number of key accounts with which CRM will be trialled. The ability to trial CRM indicates that a Real Option on CRM is present. The value of this option is the value of flexibility which reduces the risks associated with the CRM investment whilst increasing senior manager's learning about the returns of CRM for the firm. The Team estimates that it will take three years to implement and "read" the CRM trial after which time, the Board can make the decision whether or not to discontinue the trial (or scale it up) according to the firmer evidence provided by the Team's analysis of the key accounts involved. 
The DCF calculation of this fourth scenario, Trial CRM, is made on the basis of a three year trial costing $£ 36 \mathrm{M}$ in terms of CRM investment. If the trial is successful, CRM can then be extended quickly across the business. However, if the trial is unsuccessful, Westel would not extend CRM and the firm will have "lost" $£ 36 \mathrm{M}$ which puts much less investment at risk than the $£ 129 \mathrm{M}$ required for immediate implementation of CRM across the business during the same three year period. (See Appendix 1 and notes for the detailed, year-by-year calculations of Trial CRM investments and Net Contribution).

On a DCF basis alone, this option does not appear to make sense (Figure 2). The impact of the delay is to reduce the overall NPV of the CRM project to $£ 107 \mathrm{M}$; much lower than a possible $£ 133 \mathrm{M}$ for the Successful CRM scenario and only marginally better than the Gradual Decline scenario. This perhaps indicates why so many organisations have plunged into full-scale CRM rollout with sometimes costly results. Conventional DCF approaches understate the true value of trialling because they ignore the option value.

\section{Insert Figure 2}

However, the Trial scenario buys flexibility for Westel. It allows the firm to validate the Team's forecast of the impact upon revenue and costs of the CRM programme and be in a position to extend the programme across the business in a timely fashion should these benefits prove real. Flexibility and the attendant risk reduction are not cash flows and, hence, are omitted in a pure DCF comparison of the four scenarios. Mary must work with Finance to value the flexibility contained within the fourth scenario, Trial CRM. First, they need to calculate the numerical values for the five factors that affect the value of this real CRM option. These are shown in Figure 3: 


\section{Insert Figure 3}

Then, Mary and her finance colleagues use the numbers in Figure 3 to work out the value of Westel's CRM Real Option. Because of the complexity of options valuation models, they decide to calculate an approximate option valuation using look-up tables based on the Black and Scholes equations set out earlier (p11). (Brealey and Myers ${ }^{36}$ ). To find the relevant column, the asset value (£107m) must be divided by the present value of the exercise price ( $£ 195 \mathrm{~m}$ discounted at $\mathrm{r}$ of $15 \%=£ 102.2 \mathrm{~m}$ ). This comes to $1.05(£ 107 \mathrm{~m} / £ 102.2 \mathrm{~m})$.

To find the relevant row, the volatility of the underlying asset must be multiplied by the square root of the time period for which the option is available $(.32 \times \sqrt{3})=0.554$. Applying these numbers to the look-up tables, the Team is able to determine that the value of Westel's CRM option is approximately $£ 25 \mathrm{M}$.

Mary's argument to the Board is summarised in Figure 4 which shows the NPV of each scenario, including the new scenario four, Trial CRM, which also has an option value. When the value of the flexibility provided by trialling CRM is added to the cash flow generated, the total value of scenario four is very marginally lower than the potentially much higher-risk option, scenario one, of rolling out a full CRM project immediately.

\section{Insert figure 4}

By calculating the value of Westel's CRM option, the Team is in a much stronger position to recommend that the firm market tests CRM with a limited number of customers over a three year period in order to validate the business case assumptions 
about revenue and costs. The firm should then be in the position to implement a full-scale CRM programme shortly afterwards. With three years experience of CRM, Westel will be able to reduce the wide spread in NPV estimates for CRM. In other words, the firm will be able to reduce the risk of its CRM investment. This risk will also be reduced through market testing of CRM that will allow Westel to build competencies, resources and a track record of learning relationships with customers.

The discussion of risk in respect of scenario one, Successful CRM, raises an issue about the interest rate used in the calculations. The same interest rate is used in all four scenarios. However, common sense suggests that the Successful CRM scenario is more risky than the others and, as such, it should attract a higher cost of capital (discount rate). This would have the effect of reducing the NPV of Successful CRM whilst increasing the option value associated with Trial CRM since, as discussed above, the value of a Real Option varies positively with the interest rate. Thus, the approach taken to valuing Westel's CRM option may be slightly conservative.

The identification of a supportable financial value for the factors, which are not captured in the DCF, allows the Board to engage in an informed debate and make a rational assessment of the value of CRM. It addresses the Finance Director's concern about adding such values into a DCF analysis but does not fall into the trap of either ignoring the value or incorporating it in a non-transparent manner through heroic sales growth assumptions. 


\section{Managerial Implications of using Real Options for CRM Project Evaluation}

There are two important implications for CRM project managers concerning how they make the business case for CRM and the way in which they structure and implement subsequent CRM programmes. Many CRM projects fail, indicating that they are risky. In these circumstances, making a case using DCF / NPV will misrepresent the real value of projects that contain options. The greater the uncertainty, the greater the option value. Making a case for CRM based solely on DCF may deter senior managers from investing in CRM because the potential is understated.

The Westel example demonstrates the limitations of financial models (DCF/NPV) which senior managers typically use when building the business case for CRM. Faced with the constraints of considering only the immediately identifiable cash flows, firms may tend to underestimate the true value of the benefits derived from CRM, such as learning from key customers and building their trust. This means that business leaders may not invest in such a programme, leaving their firms vulnerable to competitors. Real Options can help demonstrate the true potential of CRM investment.

The CRM business case is a major strategic document and not merely a financial forecasting exercise. It represents a fundamental change to the business and should be evaluated as a strategic, risky and contingent investment in an unknown future. The challenge for senior managers is to promote a discussion that identifies the extent to which their business must move from a traditional "make and sell" model to "listen and respond" in an unknown future and real options thinking can help to generate this 
discussion.

The second implication concerns the way in which managers structure and implement CRM programmes. The Westel case illustrates the benefits of options thinking and of structuring CRM programmes to create options to defer, pilot or upscale major CRM investments. Without options thinking, companies may fail to build into the programme sufficient flexibility to learn from customers, which could compromise the huge investment that CRM requires. It can, therefore, enable a rational discussion of risk and flexibility in the search to optimise the structuring of CRM investments and the implementation of programmes. Moreover, in the time before the option must be exercised, the three years of the Westel Trial CRM in this case, senior management attention will be focused on validating the key assumptions built into the business case. This will promote a rigorous, fact-based means of quantifying CRM benefits.

\section{Acknowledgements}

We would like to offer our thanks to the three blind referees who provided valuable feedback during each drafting stage of our paper and to the continued support, advice and enthusiasm of the Editor-in-Chief.

\section{References}

${ }^{1}$ Ebner, M., Hu, A., Levitt, D. and McCrory, J., "How to Rescue CRM”, McKinsey Quarterly, Issue 4, pp. 49-57. (2002)

${ }^{2}$ Rigby, D.K., Reichheld, F.F. and Schefter, P., “Avoid the Four Perils of CRM”, Harvard 
Business Review, Vol. 80, No 2, pp.101-109. (2002)

${ }^{3}$ Benaroch, M., "Managing Information Technology Investment Risk: A Real Options Perspective", Journal of Management Information Systems, Vol.19,_No. 2, pp. 43-84. (2002)

${ }^{4}$ Reinartz, W., Krafft, M. and Hoyer, W.D., “The Customer Relationship Management Process: Its Measurement and impact on Performance", Journal of Market Research, Vol.XLI, August, pp. 293-305. (2004)

${ }^{5}$ Palmer, A., "Co-operation and Competition: a Darwinian synthesis of relationship marketing”, European Journal of Marketing, Vol. 34, No. 5/6, pp. 687-704. (2000)

${ }^{6}$ Gummesson, E., "Implementation Requires a Relationship Marketing Paradigm", Journal of the Academy of Marketing Science, Vol. 26, No. 3, pp. 242-249. (1998)

${ }^{7}$ Sheth, J.P.A., "Relationship Marketing in Consumer Markets: Antecedents and Consequences", Journal of the Academy of Marketing Science, Vol. 23, No. 4, pp. 255 271. (1995)

${ }^{8}$ Christopher, M., Logistics and Supply Chain Management, $2^{\text {nd }}$ edn, Financial Times Management, London. (1998)

${ }^{9}$ Williamson, O., "The Economics of Organisation: The Transaction Cost Approach", American Journal of Sociology, Vol. 87, No. 3, pp. 548-577. (1981)

${ }^{10}$ Degerature, A., Rangaswamy, A. and Wu, J., "Consumer Choice Behaviour and Traditional Supermarkets: the Effects of Brand Name, Price and Other Search Attributes", eBusiness Research Centre Working Paper (03, Penn State's Smeal College of Business Administration, PA.). (1999)

${ }^{11}$ Shapiro, C. and Varian, H., Information Rules, Harvard Business School Press, Boston, Mass. (1999)

${ }^{12}$ Verhoef, P.C., "Understanding the Effect of Customer Relationship Management Efforts on Customer Retention and Customer Share Development", Journal of Marketing, Vol. 67, pp. 30-45. (2003)

${ }^{13}$ Pine, J.I., Peppers, D. and Rogers, M., "Do you Want to Keep your Customers Forever?", Harvard Business Review, Vol. 73, No. 2, Mar-April, pp. 103-114. (1995)

${ }^{14}$ Wyner, G.A.,"Customer Valuation: Linking Behaviour and Economics", Marketing Research, Vol.8, Issue 2, p36, 3p. (1996)

${ }^{15}$ Johnson, L.K., "The Real Value of Customer Loyalty”, MIT Sloan Management Review, Vol.43, Issue 2, p14, 2p. (2002) 
${ }^{16}$ Reichheld, F.F., The Loyalty Effect, Harvard Business School Press, Boston, Mass. (1996)

${ }^{17}$ Corner, B.A., "Measuring Customer Relationship- Effective Metrics can help put your CR strategy to Work", Marketing Management, Vol.11, Issue 3, p.10, 2pp. (2002a)

${ }^{18}$ Peppers, D. and Rogers, M., Enterprise One to One, Currency Doubleday, New York. (1997)

${ }^{19}$ Ryals, L., “Are Your Customers Worth More Than Money?", Journal of Retailing and Consumer Services, Vol. 9, pp. 241-251. (2002)

${ }^{20}$ Wilson, C., Profitable Customers, Kogan Page, London. (1996)

${ }^{21}$ Thomke, R. and Von Hippel, E., "Customers as Innovators", Harvard Business Review, Vol. 80, No. 4, Mar-Apr, pp. 74-85. (2002)

${ }^{22}$ Womack, J.P., Jones, D.T. and Roos, D., The Machine that Changed the World, Rawson Associates, New York. (1990)

${ }^{23}$ Constable, M., "Customer Satisfaction and Trust in the Resource-Based Perspective. Research Propositions Endorsing the Confirmation/Disconfirmation Paradigm", in Marketing Relationships, 27th EMAC, Stockholm, pp 77-97. (1998)

${ }^{24}$ Corner, B.A.," Measuring Customer Relationships - Effective Metrics can help put your CR Strategy to Work", Marketing Management, Vol.11, Issue 3, p11, 2p. (2002b)

${ }^{25}$ Coyles, S. and Gokey, T.C., "Customer Retention is not Enough", The McKinsey Quarterly, No. 23, pp.81-89. (2002)

${ }^{26}$ Maklan, S., "The Business Case for CRM: What IS Needs to Know", CSC Foundation Research Journal, No. 2, pp. 68-74. (2000)

${ }^{27}$ Fournier, S., Dobscha, S. and Mick, D., "Preventing the Premature Death of Relationship Marketing”, Harvard Business Review, Vol. 76, No. 1, Jan-Feb, pp. 42 -51. (1998)

${ }^{28}$ Olazabal, G., "Banking: The IT Paradox", The McKinsey Quarterly, No. 1, pp. 47 -51. (2002)

${ }^{29}$ PriceWaterhouseCoopers, 'Multi-channel Value Qualification', www.pwcconsulting.com/us/pwcons.nsp/viewwebpages/crmsurvey. (2004)

${ }^{30}$ Ryals, L. J., Knox, S.D. and Maklan, S., Customer Relationship Management, Research in Practice Series, FT Prentice Hall, London. (2000) 
${ }^{31}$ Knox, S.D., Maklan, S., Payne, A., Peppard, J. and Ryals, L.J., Customer Relationship Management: Perspectives from the Marketplace, Butterworth Heinemann, Oxford. (2003)

${ }^{32}$ Copeland, T., Koller, T. and Murrin, J., Valuation: Measuring and Managing the Value of Companies, Wiley, New York. (1995)

${ }^{33}$ Parmenter, D., Larréché, J-C, and Lovelock, C., "First direct: Branchless Banking", An Insead Case, No. 597-028-1. (1997)

${ }^{34}$ Luehrman, T. A., "Real Options: Getting Started on the Numbers", $\underline{\text { Harvard Business }}$ Review, Vol. 67, No. 4, Jul-Aug, pp. 51-67. (1998)

${ }^{35}$ Copeland, T. and Keenan, D., "How much is flexibility worth?", The McKinsey Quarterly, No. 2, pp. 38-49. (1998)

${ }^{36}$ Buckley, A. and Tse, K., "Real Operating Options and Foreign Direct Investment: A Synthetic Approach.” European Management Journal, Vol.14,No. 3, pp. 304-314. (1996)

${ }^{37}$ McGrath, R. G. and MacMillan, I. C., 'Assessing Technology Projects Using Real Options Reasoning', Research Technology Management, Jul/Aug2000, Vol. 43 Issue 4, pp. 35-49. (2000).

${ }^{38}$ McGrath, R. G., Ferrier, W. J. and Mendelow, A. L.. 'Real Options as Engines of Choice and Heterogeneity", Academy of Management Review, Vol. 29 Issue 1, Jan.,pp86-101, (2004)

${ }^{39}$ Amram, M. and Kulatilaka, N., Real Options, Harvard Business School Press, Boston. (1999)

${ }^{40}$ Dias, S. and Ryals, L.J., "Options Theory and options thinking in valuing returns on brand investments and brand extensions", Journal of Product and Brand Management, Vol. 11, Issue 2, pp.115-128. (2002)

${ }^{41}$ Boer, F. P., "Valuation of Technology Using 'Real Options"”, Research Technology Management , Vol. 43, No. 4, pp. 26-30. (2000)

${ }^{42}$ McGrath, R. G., Ferrier, W. J. and Mendelow, A. L., "Real Options as Engines of Choice and Heterogeneity", Academy of Management Review, Vol. 29, No.1, pp. 86101. (2004)

${ }^{43} \mathrm{Li}, \mathrm{X}$. and Johnson, J. D., "Evaluate IT Investment Opportunities Using Real Options Theory", Information Resource Management Journal, Vol. 15, No. 3, pp. 32-47. (2002)

${ }^{44}$ Kulatilaka, N., Balasubramanian, P. and Strock, J., "Using Real Options to Frame the IT Investment Problem", in Real Options and Business Strategy: Applications to Decision-Making, Ed. L. Trigeogis, pp. 185-224. Risk, London. (1999) 
${ }^{45}$ Peppers, D., Rogers, M. and Dorf, B., The One to One Fieldbook. Capstone, Oxford. (1999) 
${ }^{46}$ Brealey, R and Myers, S., Principles of Corporate Finance, McGraw-Hill, New York, $7^{\text {th }}$ edition. (2003) 


\section{Long Range Planning, Volume 38, Issue 4,}

\section{August 2005, Pages 393-410}

\section{Exhibit A}

The value of an option depends on five factors:

1. The value of the underlying asset $\left(\mathrm{P}_{\mathrm{s}}\right)$

2. The amount it costs to exercise the option (E)

3. The interest rate (r)

4. The period for which the option is available ( $t$ )

5. The volatility of the underlying asset $\left(\mathrm{N}_{\mathrm{d}}\right)$

The value of an option is given by the equation:

$\mathrm{P}_{0}=\mathrm{P}_{\mathrm{s}} \mathrm{N}\left(d_{1}\right)-\underset{\mathrm{e}^{\mathrm{rt}}}{\mathrm{E}} \mathrm{N}\left(d_{2}\right)$

where e is an exponential constant

The value of the option is related positively to all these factors except the second, the exercise price (E). In other words, the bigger the value of the underlying asset $\left(\mathrm{P}_{\mathrm{s}}\right)$, the higher the interest rate (r), the longer the period for which the option is available $(\mathrm{t})$, and the greater the volatility in value of the underlying asset $\left(\mathrm{N}_{\mathrm{d}}\right)$, the higher the value of the option is to buy (Amram and Kulatilaka, 1999 ${ }^{39}$ ). 
Figures: Long Range Planning, Volume 38, Issue 4, August 2005, Pages 393-410

\begin{tabular}{|l|l|l|l|}
\hline \multicolumn{4}{|c|}{ Figure 1: NPV Analysis of the Three Scenarios } \\
\hline & \multicolumn{1}{|c|}{$\begin{array}{c}\text { Successful CRM } \\
(£ \mathrm{M})\end{array}$} & $\begin{array}{c}\text { No Change } \\
(£ \mathrm{M})\end{array}$ & $\begin{array}{c}\text { Gradual Decline } \\
(£ \mathrm{M})\end{array}$ \\
\hline $\begin{array}{l}\text { CRM Investment } \\
\text { over 10 years }\end{array}$ & 227 & 0 & 0 \\
\hline $\begin{array}{l}\text { CRM investment } \\
\text { over first three years }\end{array}$ & 129 & 0 & 0 \\
\hline $\begin{array}{l}\text { Total revenue in year } \\
10\end{array}$ & 860 & 500 & 380 \\
\hline $\begin{array}{l}\text { Gross margin in year } \\
10\end{array}$ & 383 & 200 & 144 \\
\hline $\begin{array}{l}\text { Net contribution in } \\
\text { year 10 }\end{array}$ & 106 & 25 & 11 \\
\hline R\&D in year 10 & 108 & 75 & 57 \\
\hline NPV of scenarios & $\mathbf{1 3 3}$ & $\mathbf{1 2 5}$ & $\mathbf{9 8}$ \\
\hline
\end{tabular}


Long Range Planning, Volume 38, Issue 4, August 2005, Pages 393-410

Figure 2: NPV Estimates for the Three Scenarios plus Trial

\begin{tabular}{|c|c|}
\hline Scenario & $\begin{array}{l}\text { NPV } \\
(£ \text { M) }\end{array}$ \\
\hline Successful CRM & 133 \\
\hline No Change & 125 \\
\hline Gradual Decline & 98 \\
\hline Trial CRM & 107 \\
\hline
\end{tabular}


Long Range Planning, Volume 38, Issue 4, August 2005, Pages 393-410

\begin{tabular}{|l|l|c|l|}
\hline \multicolumn{4}{|c|}{ Figure 3: Factors affecting the value of Westel's CRM Real Option } \\
\hline & Valuation Factor & Value & Basis of Calculation \\
\hline $\mathrm{P}_{\mathrm{s}}$ & Value of the underlying asset & $£ 107 \mathrm{M}$ & $\begin{array}{l}\text { Discounted cash flows } \\
\text { over project life }\end{array}$ \\
\hline $\mathrm{E}$ & Amount it costs to exercise the option & $£ 195 \mathrm{M}$ & $\begin{array}{l}\text { Total CRM spend in the } \\
\text { fourth scenario }\end{array}$ \\
\hline $\mathrm{r}$ & Interest rate & $15 \%$ & Given by Finance \\
\hline $\mathrm{t}$ & Period for which the option is available & 3 years & Suggested by Mary \\
\hline $\mathrm{N}_{\mathrm{d}}$ & Volatility of the underlying asset & $32 \%$ & $\begin{array}{l}\text { Standard deviation of } \\
\text { cash flows from the } \\
\text { project. }\end{array}$ \\
\hline
\end{tabular}


Long Range Planning, Volume 38, Issue 4, August 2005, Pages 393-410

\begin{tabular}{|l|c|l|l|}
\hline \multicolumn{3}{|c|}{ Figure 4: Assessing CRM Investment Scenarios with Real Options } \\
\hline \multicolumn{1}{|c|}{ Scenario } & $\begin{array}{c}\text { NPV } \\
(£ \mathrm{M})\end{array}$ & $\begin{array}{c}\text { Real Option Value } \\
(£ \mathrm{M})\end{array}$ & $\begin{array}{c}\text { Total Value } \\
(\text { Real Option plus NPV } \\
£ \mathrm{M})\end{array}$ \\
\hline Successful CRM & 133 & 0 & 133 \\
\hline No Change & 125 & 0 & 125 \\
\hline Gradual Decline & 98 & 0 & 98 \\
\hline Trial CRM & 107 & 25 & 132 \\
\hline
\end{tabular}




\section{Appendix 1: Income Statement (EM)}

\section{1: Successful CRM Scenario}

$\begin{array}{llllllllll}\mathrm{Y1} & \mathrm{Y} 2 & \mathrm{Y3} & \mathrm{Y} 4 & \mathrm{Y5} & \mathrm{Y6} & \mathrm{Y7} & \mathrm{Y} 8 & \mathrm{Y9} & \mathrm{Y} 10\end{array}$

\begin{tabular}{|c|c|c|c|c|c|c|c|c|c|c|c|}
\hline Revenı & $\begin{array}{l}\text { eurrent } \\
\text { Increased "cross sell" } \\
\text { New referrals } \\
\text { New business ideas } \\
\text { Total Revenue } \\
\end{array}$ & $\begin{array}{r}500 \\
12 \\
5 \\
0 \\
517 \\
\end{array}$ & $\begin{array}{r}500 \\
24 \\
10 \\
0 \\
534 \\
\end{array}$ & $\begin{array}{r}500 \\
42 \\
25 \\
1.5 \\
568.5 \\
\end{array}$ & $\begin{array}{r}500 \\
50 \\
35 \\
10 \\
595 \\
\end{array}$ & $\begin{array}{r}500 \\
62 \\
50 \\
30 \\
642 \\
\end{array}$ & $\begin{array}{r}500 \\
80 \\
70 \\
50 \\
700 \\
\end{array}$ & $\begin{array}{r}500 \\
84 \\
80 \\
60 \\
724 \\
\end{array}$ & $\begin{array}{r}500 \\
90 \\
90 \\
80 \\
760 \\
\end{array}$ & $\begin{array}{l}500 \\
100 \\
100 \\
110 \\
810 \\
\end{array}$ & $\begin{array}{l}500 \\
110 \\
110 \\
140 \\
860 \\
\end{array}$ \\
\hline \multicolumn{2}{|c|}{ Gross Margin \% Revenue } & .400 & .405 & .410 & .415 & .420 & .425 & .430 & .435 & .440 & .445 \\
\hline \multicolumn{2}{|c|}{ Gross Margin } & 207 & 216 & 233 & 247 & 270 & 298 & 311 & 331 & 356 & 383 \\
\hline Other* & $\begin{array}{l}\text { SG\&A } \\
\text { R\&D } \\
\text { Total costs\% Revenue }\end{array}$ & $\begin{array}{l}.200 \\
.150 \\
.350\end{array}$ & $\begin{array}{l}.200 \\
.145 \\
.345\end{array}$ & $\begin{array}{l}.195 \\
.145 \\
.340\end{array}$ & $\begin{array}{l}.195 \\
.140 \\
.335\end{array}$ & $\begin{array}{l}.190 \\
.140 \\
.330\end{array}$ & $\begin{array}{l}.190 \\
.135 \\
.325\end{array}$ & $\begin{array}{l}.190 \\
.135 \\
.325\end{array}$ & $\begin{array}{l}.185 \\
.130 \\
.315\end{array}$ & $\begin{array}{l}.185 \\
.130 \\
.315\end{array}$ & $\begin{array}{l}.180 \\
.125 \\
.305\end{array}$ \\
\hline \multicolumn{2}{|c|}{ Other costs } & 181 & 184 & 193 & 199 & 212 & 228 & 235 & 239 & 255 & 262 \\
\hline \multicolumn{2}{|c|}{ Contribution excluding CRM costs } & 26 & 32 & 40 & 48 & 58 & 70 & 76 & 91 & 101 & 120 \\
\hline \multicolumn{2}{|c|}{$\begin{array}{c}\text { Incremental CRM Costs } \\
\text { Technology } \\
\text { Reorganisation } \\
\text { People } \\
\text { Marketing } \\
\text { Total }\end{array}$} & $\begin{array}{l}40 \\
10 \\
10 \\
10 \\
70\end{array}$ & $\begin{array}{r}25 \\
5 \\
5 \\
10 \\
45\end{array}$ & $\begin{array}{r}5 \\
0 \\
5 \\
4 \\
14\end{array}$ & $\begin{array}{r}5 \\
0 \\
5 \\
4 \\
14\end{array}$ & $\begin{array}{r}5 \\
0 \\
5 \\
4 \\
14\end{array}$ & $\begin{array}{r}5 \\
0 \\
5 \\
4 \\
14\end{array}$ & $\begin{array}{r}5 \\
0 \\
5 \\
4 \\
14\end{array}$ & $\begin{array}{r}5 \\
0 \\
5 \\
4 \\
14\end{array}$ & $\begin{array}{r}5 \\
0 \\
5 \\
4 \\
14\end{array}$ & $\begin{array}{r}5 \\
0 \\
5 \\
4 \\
14\end{array}$ \\
\hline \multicolumn{2}{|c|}{ Net Contribution } & -44 & -13 & 26 & 34 & 44 & 56 & 62 & 77 & 87 & 106 \\
\hline
\end{tabular}

* excludes CRM programme and investment 


\section{2: No Change Scenario}

\begin{tabular}{|c|c|c|c|c|c|c|c|c|c|c|c|}
\hline \multirow[t]{2}{*}{ Revent } & $\begin{array}{l}\text { Current } \\
\text { Increased "cross sell" } \\
\text { New referrals } \\
\text { New business ideas }\end{array}$ & 500 & 500 & 500 & 500 & 500 & 500 & 500 & 500 & 500 & 500 \\
\hline & Total Revenue & 500 & 500 & 500 & 500 & 500 & 500 & 500 & 500 & 500 & 500 \\
\hline \multicolumn{2}{|c|}{ Gross Margin \% Revenue } & 0.4 & 0.4 & 0.4 & 0.4 & 0.4 & 0.4 & 0.4 & 0.4 & 0.4 & 0.4 \\
\hline \multicolumn{2}{|c|}{ Gross Margin } & 200 & 200 & 200 & 200 & 200 & 200 & 200 & 200 & 200 & 200 \\
\hline Other* & $\begin{array}{l}\text { SG\&A } \\
\text { R\&D } \\
\text { Total costs\% Revenue }\end{array}$ & $\begin{array}{l}.20 \\
.15 \\
.35\end{array}$ & $\begin{array}{l}.20 \\
.15 \\
.35\end{array}$ & $\begin{array}{l}.20 \\
.15 \\
.35\end{array}$ & $\begin{array}{l}.20 \\
.15 \\
.35\end{array}$ & $\begin{array}{l}.20 \\
.15 \\
.35\end{array}$ & $\begin{array}{l}.20 \\
.15 \\
.35\end{array}$ & $\begin{array}{l}.20 \\
.15 \\
.35\end{array}$ & $\begin{array}{l}.20 \\
.15 \\
.35\end{array}$ & $\begin{array}{l}.20 \\
.15 \\
.35\end{array}$ & $\begin{array}{l}.20 \\
.15 \\
.35\end{array}$ \\
\hline \multicolumn{2}{|c|}{ Other costs } & 175 & 175 & 175 & 175 & 175 & 175 & 175 & 175 & 175 & 175 \\
\hline \multicolumn{2}{|c|}{ Net Contribution } & 25 & 25 & 25 & 25 & 25 & 25 & 25 & 25 & 25 & 25 \\
\hline
\end{tabular}

Discounted

* excludes CRM costs

Long Range Planning, Volume 38, Issue 4, August 2005, Pages 393-410 
3: Gradual Decline Scenario

\begin{tabular}{|c|c|c|c|c|c|c|c|c|c|c|c|}
\hline Revenı & $\begin{array}{l}\text { Declining Revenue } \\
\text { Increased "cross sell" } \\
\text { New referrals } \\
\text { New business ideas }\end{array}$ & 500 & 485 & 470 & 456 & 443 & 429 & 416 & 404 & 392 & 380 \\
\hline & Total Revenue & 500 & 485 & 470 & 456 & 443 & 429 & 416 & 404 & 392 & 380 \\
\hline Gross 1 & largin \% Revenue & .400 & 0.4 & 0.395 & 0.395 & 0.39 & 0.39 & 0.385 & 0.385 & 0.38 & 0.38 \\
\hline Gross 1 & largin & 200 & 194 & 186 & 180 & 173 & 167 & 160 & 156 & 149 & 144 \\
\hline Other* & $\begin{array}{l}\text { SG\&A } \\
\text { R\&D } \\
\text { Total costs } \% \text { Revenue }\end{array}$ & $\begin{array}{l}.20 \\
.15 \\
.35\end{array}$ & $\begin{array}{l}.20 \\
.15 \\
.35\end{array}$ & $\begin{array}{l}.20 \\
.15 \\
.35\end{array}$ & $\begin{array}{l}.20 \\
.15 \\
.35\end{array}$ & $\begin{array}{l}.20 \\
.15 \\
.35\end{array}$ & $\begin{array}{l}.20 \\
.15 \\
.35\end{array}$ & $\begin{array}{l}.20 \\
.15 \\
.35\end{array}$ & $\begin{array}{l}.20 \\
.15 \\
.35\end{array}$ & $\begin{array}{l}.20 \\
.15 \\
.35\end{array}$ & $\begin{array}{l}.20 \\
.15 \\
.35\end{array}$ \\
\hline Other c & sts & 175 & 170 & 165 & 160 & 155 & 150 & 146 & 141 & 137 & 133 \\
\hline Net Co & tribution & 25 & 24 & 21 & 21 & 18 & 17 & 15 & 14 & 12 & 11 \\
\hline
\end{tabular}

${ }^{*}$ excludes CRM costs

\section{Long Range Planning, Volume 38, Issue 4, August 2005, Pages 393-410}




\section{4: Trial CRM Scenario}

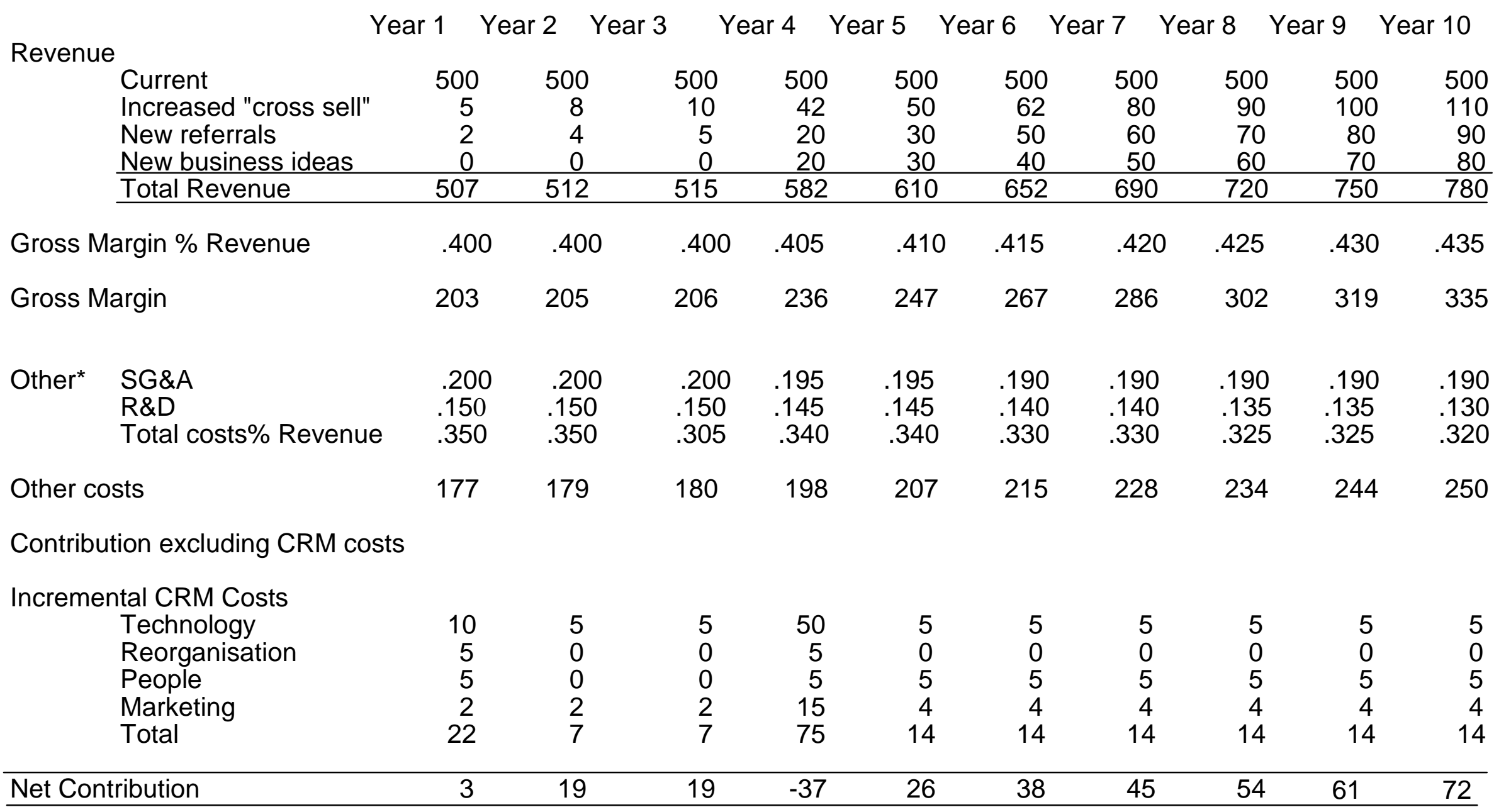




\section{Notes for Appendix 1: Successful CRM}

\section{Revenue}

This scenario assumes that the current revenue of $£ 500 \mathrm{M}$ is successfully defended through CRM. This base is augmented by layers of incremental revenues identified in the case. The incremental revenues are estimates generated by Mary in conjunction with partners in Sales and outside consultants with experience in CRM programme development. In order of importance, these incremental revenues are:

- Increased cross selling to current customers. The immediate focus of CRM is to extend and enhance that which Westel sells to its customers, leveraging its good reputation and incumbency in major users of telecoms equipment. Whilst there are some revenues generated in year 1, the impact of cross selling will grow over subsequent years as Westel learns how to profit from enhanced relationships. The rate of revenue growth decreases in the final years of the 10 year period to reflect eventual diminishing returns from cross selling.

- New referrals. The CRM programme will identify those customers for whom Westel is adding the most value and where the relationship is strongest converting customers' good will towards Westel into sales leads, references and general endorsement of Westel's qualities. Referrals, references and endorsements are important win-bidding developments for large telecoms infrastructure projects, given the amount of money and risk they entail. The referral effect also starts slowly, grows more rapidly for a few years and then tails off in the later years of the forecasted period.

- New business ideas. This is the most difficult area to estimate as it estimates the ability of Westel to exploit commercially ideas that are generated through learning from future customer interactions. The revenue generation is lagged to the learning to reflect the time it takes to work more intimately with clients, develop new ideas with them, assess their wider commercial potential and introduce the new ideas to a larger number of customers. The forecast suggests that it will take almost four years to realise any significant income from this form of learning from customers.

\section{Gross margin}

CRM will allow Westel to allocate better its resources and re-engineer its business processes to provide more of what its best customers value and less of what customers do not appreciate or are unwilling to pay for. This better matching of resources and processes to customer value will reduce costs incurred that add little value and allow 
Westel to produce more valued services and products, which all else being equal, should sell at premium prices. The revenue from this is assumed to be lagged by one year to the start of CRM but adds one-half point of margin thereafter. The final figure of $44.5 \%$ is considered by Mary to be achievable in consideration of her analysis of best-practice competitors.

\section{Other Costs}

These increase in absolute terms over 10 years but not as fast as income. For example, R\&D increases from its current level of $£ 75 \mathrm{M}$ (15\% of $£ 500 \mathrm{M}$ turnover) to $£ 107.5$ $\mathrm{M}$ (12.5\% of year 10 turnover). Moreover, $R \& D$ priorities will be more targeted on specific customer opportunities and hence less speculative and more cost-effective.

\section{Incremental CRM Costs}

\section{Technology}

This comprises CRM software implementation over 18 months. The major components are sales force automation, new customer contact (call) centre, enhanced web access, new customer database, new database analysis tools and improved integration of the contact centre with Westel's logistic and billing systems. Integrating these new sales, marketing and service systems together and then to the back office support systems is a major systems development. The logistics and billing systems had not been built to integrate seamlessly into new, state-of-the-art front office systems that Westel would need and would require extensive use of outside systems development and integration consultants. The new front office equipment would stretch existing computer hardware and servers beyond their capability and new equipment would be needed.

The key investments are as follows:

New sales systems to 1000 field sales people

$£ 10,000,000$

New lap tops to field sales people

$5,000,000$

New sales systems to 500 desk based sales people $\quad 2,500,000$

New service software for 1000 service people

$5,000,000$

New marketing systems for 500 marketers

$2,500,000$

Other new hardware (servers, LANs, etc)

$2,500,000$

New database and analytical tools

$5,000,000$

Systems integration, process development (consulting fees) $\quad 17,500,000$

Upgrades to logistics and billing systems

$15,000,000$

Total

$65,000,000$ 
The investment was front loaded with $£ 40 \mathrm{M}$ in the first year and $£ 25 \mathrm{M}$ in year two. Commencing in year three, IT estimated an ongoing cost of $£ 5 \mathrm{M}$ per annum for software upgrades, license fees and miscellaneous new maintenance costs.

\section{Reorganisation}

The sales force would be reorganised into profit-responsible customer teams and lead Westel's business and product planning processes. It would need new competencies in customer development, planning, financial analysis, risk assessment and budgeting. Product groups would need a reorientation to adapt a more "listen and serve" approach to their jobs. This represented the biggest-ever change for Westel's Sales organisation in its history.

After advice from change-management consulting firms, Mary estimated an 18 month implementation of the change with $£ 15$ million, one-off cost spread equally over the period; $£ 10$ million in year one and $£ 5$ million in the second year. The costs relate to hiring outside change-management consultants and facilities, food and travel for the attendant workshops and re-training sessions.

\section{People}

Not all the current Westel people would be able and or willing to make the transition from a product to a customer-led structure. Mary estimated that $20 \%$ of the current marketing and sales people would either leave or be replaced during the first 18 months of the CRM implementation.

Mary worked with HR specialists to estimate the costs involved. In considering the people, their flexibility and ongoing level of staff turnover, the specialists suggest a first year cost of $£ 10$ million relating to personal coaching and training for those that can make the transition to key account management, coaching of others to consider other opportunities within Westel and severance pay for those that will neither make the transition to the new organisation nor find an acceptable position elsewhere. There will be only limited recruitment from the outside in the first year of the CRM programme to allow Westel people the best opportunity and minimise disruption. Thereafter, there is a cost of $£ 5 \mathrm{M}$ per annum for recruiting new people and additional severance pay.

\section{Marketing}

Westel did not traditionally spend heavily in marketing, instead relying on its reputation and sales force for reputation and positioning. Current marketing budgets were hard to estimate as spending was fragmented across individual product groups and not always identified as marketing. Mary was convinced that repositioning Westel from hardware vendor to solutions-partner would require a much larger investment in marketing communications behind the corporate brand. Westel had never before invested specifically in corporate brand building. 
During the first two years of the change programme, Mary budgeted for a $£ 20$ million global communication programme directed at customers and opinion-formers. The objectives of the communication programme were to promote the new strategy and discourage rumours that Westel lacks a clear strategy. Thereafter marketing budgets would fall to approx. $£ 4$ million per annum, but not to the very low current levels. Mary felt that as Westel changed its focus from product-marketing to customersolutions, it would need to maintain a strong corporate brand to endorse its credentials as a long-term business partner.

\section{Notes for Appendix 1: Trial CRM}

Mary is able to identify a limited number of customers with whom Westel can engage in the type of relationship that is planned for all customers under the "successful CRM scenario". The technology, reorganisation, people and marketing investments required are as per above, but on a much smaller scale. Many of the software solutions can be delayed during the trial in favour of enhancements to current systems and additional staff. These short-term fixes are not scaleable to support all of Westel's business but can be operated for a limited time for a limited number of companies.

This scenario illustrates a three year investment that is successful and hence allows Westel to extend CRM across the company in year 4 . The slower pace of implementation is actually less expensive in a few areas over a four year period because it avoids the disruptiveness of quick-paced, major change (e.g. People costs). However the major assumptions about the extent and pace of incremental revenue development and technology costs are very similar to those used in the successful CRM scenario albeit lagged to reflect the three year test market. 